\title{
Stoa Felsefesinde Sağaltımın İzleri: Bir Pratik Yaşam Felsefesi
}

\section{Traces of Healing in Stoic Philosophy: A Philosophy of Practical Life}

\section{Dilnur KARABULUT * Ekin KAYNAK ILTAR **}

\begin{abstract}
$\ddot{O}_{z}$ : Bir yaşam tarzı olarak felsefe, insanın çevresiyle anlamlı bir ilişsi kurmasını sağlar. Bu çalışmada birçok düşünürün üzerinde durduğu mutluluk kavramından hareketle sağaltımın ne anlama geldiği, Stoa felsefesinde bulduğumuz tespitlerle insanın kendini iyileștirebilmesi arasındaki ilişki ele alınacaktır. Stoa felsefesindeki bu tavır, dünyanın metafiziksel yanının tartışılmasından çok, nasıl yaşamayı daha anlamlı kıldığımız gibi kuram - eylem bütünlüğü içerisinde bir yaşam tavrıdır.Dünyevi meseleleri çözümlemek için düşüncelerinde pratik felsefeyi öne çıkaran Stoalı filozoflar, bizde sağaltımsal gerekçeleri bulma merakı uyandırmaktadır. Bu nedenle Stoalı filozofların düşünce hastalığıyla mücadele etme gerekliliğinin nedenleri üzerinde durarak, çeşitli çözüm önerileri sunulacaktır. Dolayısıyla Stoalıların felsefi iyileşmeyi nasıl anladıkları değerlendirilecektir.Kendi dönemlerinde yaşam tarzlarıyla bütünleştirerek uygulamalı olarak ortaya koydukları ahlak felsefelerinin topluma katkıları, bizim bu yola girmemizin temel nedenlerinden biridir. İnsanları Stoa felsefesinin tedavisel yanından haberdar etmek, kendilerini bir bütünün parçası olarak görmelerine hem kendilerine hem çevresindekilere hem de doğaya daha anlamlı bir şekilde bakılmasını sağlayacaktır. Dolayısıyla çalışmamızda Stoa felsefesinin iyileştirici yanının bir yaşam pratiği bağlamında ele alınmış olmasının temellerini ve dönemimizdeki etkilerini gözden geçirdiğimizde; bu felsefenin merkezinde yer alan iyileştirmeye, insanın düşüncelerini temizlemeye ve tedavi etmeye yönelen bu felsefi anlayışın, mutluluğu arayan insan için bir rehber olarak dünden bugüne varlığını koruyarak devam eden bir ekol olduğunu görmek mümkün olacaktır.
\end{abstract}

Anahtar sözcükler: Stoa Felsefesi, Sağaltım, Pratik Yaşam, Mutluluk Yolu Metodu

Abstract: Philosophy as a way of life enables the establishment of meaningful relationship with the environment. In this, the meaning of treatment based on the concept of happiness emphasized by many thinkers, the relationship between the determinations found the Stoa and self-healing are discussed. This attitude of the stoa's, rather than the discussion of the metaphysical side, life within the unity of theory and action, as living is made more meaningful. The Stoa's put forward practical philosophy in thought to solve worldly issues, aroused curiosity in finding therapeutic reasons. These reasons, various solutions are presented by emphasizing. The Stoics' understanding of philosophical healing is evaluated. The contributions of the philosophies of morality, which they put forward by integrating with their lifestyles are reasons for our entering this path. Informing people about the therapeutic of the Stoa will allow a meaningful look at both their surroundings and nature. Therefore, when we review the basics of the healing side of the Stoa within the context of life practice and the effects period; it will be possible to see that this philosophical understanding, which is at the center of this philosophy, which aims to improve, to cleanse and to treat human thoughts, is a school that continues from past to present, forming a guide for people seeking happiness

Keywords: Stoa Philosophy, Philosophical healing, Pratical life, Happiness Path Method

\footnotetext{
* Ph.D., Akdeniz Üniversitesi, Edebiyat Fakültesi, Felsefe Bölümü, Antalya. dilnurk@gmail.com, https://orcid.org/ 0000-0003-4209-0270

** Dr. Öğr. Ü, Akdeniz Üniversitesi, Edebiyat Fakültesi, Felsefe Bölümü, Antalya. ekinkaynak@ akdeniz.edu.tr, https://orcid.org/0000-0001-5190-207X
} 


\section{Giriş}

Mutluluk kavramı, çoğu filozofun üzerinde fikir yürüttüğü en temel kavramlardan biri olagelmiştir. Günümüzde, özellikle ruhu dinginleştirmeye ve zihni sağlıklı düşünmeye yönelten çeşitli yaklaşımlar gittikçe artan alternatif tedavi yöntemleri karşısında, felsefenin başka alanlara kayması kaçınılmazdır. Üstelik Batı'da gittikçe uzmanlaşılan bir felsefi terapiler alanı düşünüldüğünde çağa ayak uydurmak, ilk çağ felsefesine yeni perspektiften okumalar sunarak yeni düşünceler geliştirmek yegane arzumuzdur. Bu bağlamda felsefi sağaltım insanın insanla ve insanın insanlıkla tedavisini amaçlar. Bu tedavi ya da sağaltımı filozof kendi başına yapmaz; içeridekiler, yani 'hastalar'ı doğa bilimi ile, 'dışarıdakiler'i ise, bütün birikimiyle -Tıp da dahilgerçekleştirme çabasını güder (Filiz 2018, 11).

Antik Yunan'da sağlıklı düşünme yolları üzerine okumalarımızı derinleştirdiğimizde, bu alana düşünce ve eylemleriyle yakın olan belli ekoller dikatleri çekmektedir. Tam olarak söz konusu 'sağaltım' kavramını bire bir yakalayamasak da, bu ekollerden Stoalıların Okulu, felsefi düşünce anlayışlarıyla kastedilen kavramla örtüşen metotlar geliştirmişlerdir. Günümüzde ise farklı ülkelerdeki farklı kuruluşların nihai çabalarıyla geliştirilen bir ekolün yöntem biçimi olarak devam etmektedir.

İlk çalışmaların 1986'da Almanya'da ve 1996'da ABD'de akademik bir alanda yapıldığ felsefi klinikler, Batı'da bir çok yerde tıp bilimleri ile ortaklaşa tedavi yöntemleri aramıştır. Belirtmek gerekir ki yeni yorumsamacı ve açıklamacı çalışma modelleriyle ülkemiz de bu genel eğilimin akışına ayak uydurmaktadır. Multidisipliner ve yorumsamacı yaklaşıma yöneliş, bu türden bir yaklaşımı içselleştirmeyle birlikte yeni kamusal alanlar oluşturulmasına ihtiyaç duyulmasına yol açmıştır.

Günümüzde zihinsel rahatlamanın güncel bir şekilde ihtiyaç olduğu varsayımı, bu konuda yöntembilimsel kuramların çeşitliliği, felsefi temellendirmelerle felsefi sağaltım yaklaşımları gibi metotların yaygınlaşmasıyla yeni bir tartışma alanı açılmıştır. Denilebilir ki bu tür yaklaşımların amacı alternatif tedavi değil; bunun öncesinde önlem almaktır. Çünkü felsefi sağaltım, hastalığın görülür biçimde davranışa dökülmesinden daha erken bir zamanda felsefe tarihinin yardımıyla zihne sağlıklı düşünmeyi öğretmeyi amaçlamaktadır. Dolayısıyla bu amaç, tıbbi bir tedavinin çok ötesinde varoluşsal bir iyileşmeyi kapsar.

Sınırlı bir sürem kaldığında nasıl yaşamalıyım? Toplum içerisinde nasıl mutlu olabilirim ve nasıl ahlaki davranabilirim? Hangi mesleği yapabilirim? Çocuk sahibi olmalı mıyım? Dürtülerimi ve arzularımı takip etmeli miyim veya eş/partnerime sadık kalmalı mıyım? Hastalığım karşısında nasıl mutlu bir hayat sürebilirim? (Wahler 2013, 55) gibi sorulara cevap arayışında bulunmak, günlük hayatta bize felsefi yaşam danışmanlığını yapacak kavram, teori ve yöntemler sunması adına önemli ipuçlarını verir.

Sonuç olarak felsefi sağaltım, felsefi söylemin uygulamada nihayetsiz çabalara dayandığı ve günlük etkinliklerde araçsallaştırılamadığı savını da temelsiz bırakmıştır. İnsan yaşamını tek yönlü boyutuyla ele alan öğretilerin, Stoa felsefesinin insanı kuram ve eylemleriyle bir bütün olarak düşünen ve hem biyolojik hem de psikolojik boyutunu birlikte ele alan çok yönlülüğü karşısında, insanı ele alan çeşitli psikoloji alanlarının tek boyutluluğuyla yetersiz kaldığı açıkça görülmektedir.

Filozofların insanlar için sağlık, hastalık ve normallik kavramları üzerinde durduğu gibi son zamanlarda tıbben anlamlı tanımlama çalışmaları yapılmıştır. Tıp etiği gibi böyle özel tıbbi normlar, yaşam biçimlerini ve koşullarını toplu olarak tanımlar (Becker 2003, 222). Ancak felsefe ile bir tavır kazanan disiplinler, mutlu olma yolunun hem doğayla ilişkide hem de dünyaya karşı kayıtsız kalmada ortaya çıkan görünümleri, rasyonel ve psişik bir varlık olan insanın ahlaki kararlarıyla bir amaca ulaşır. Felsefenin uygulamasında (pratiğinde) felsefi yaşam 
danışmanlığı, psikoterapinin karşısında alternatif olarak kurulur. Felsefi uygulama, sorunlar veya endişelerle acı çeken, yaşamlarıyla başa çıkamayan veya bir şekilde sıkışıp kaldıklarını düşünen insanlar için bir müessesedir (Achenbach 2010, 16).

Içinde yaşadığımız dünyayı, şimdi ve buradayı, yaşamı ilgi alanı yapan, bunun üzerine felsefesini kurarak eğitimini veren Alman Enstitüsü, Viyana Üniversitesi, İngiltere-Londra okulu, Avusturya Daseinanaliz Enstitüsü, Universitat Wien Philosophische Praxis Okulu gibi dünyanın çeşitli bölgelerinde açılan felsefi terapi kuruluşlarını düşünürsek, çağımızın bu alana evrildiğini görmüş oluruz.

\section{Bir Pratik Yaşam Felsefesi Geliștiren Stoalılar}

Yaklaşık beş yüzyıl kadar devam eden ve hala etkisi görülen Stoa okulu erken ya da ilk dönem olarak başta Zenon (MÖ 344-262), Cleanthes (MÖ 331-233) ve Chrysippus (MÖ 281-208) tarafından kurulmuştur. Fakat Diogenes Laertius, Stoabaeus, Cicero, Plutarchus, Simplicius, Sextus Empiricus gibi filozofların birincil kaynakları günümüze kadar korunmuştur. Orta Stoa ya da ikinci dönemin önemli filozofları Panaetius (MÖ 185-110) ve Poseidonius (MÖ 135-51) da çeşitli çalışmalar yapmıştır. Geç Stoa ya da üçüncü dönem önemli filozofları ise Seneca (MS 65), Epictetus (MS 50-138) ve Marcus Aurelius (MS 121-180) çalışmamızda daha etkili olmuştur. Geç Stoa döneminde ahlak felsefesine yönelerek bir pratik felsefe oluşturmaları ve kendinden önce gelen Stoalı düşünürlerin öğretilerini uygulamayla ilgilenmeleri bizim konumuz itibariyle neden bu dönemle ilgilendiğimizin temel nedenidir.

MÖ IV. ile MS V. yüzyıl arasındaki dönem olan Hellenistik Felsefe dönemiyle dört büyük okul ortaya çıkmıştır. Genel olarak bu okullar mantık, fizik ve ahlak konularıyla ilgilenmişlerdir.

Stoalıların yaşadıkları bu dönemde denilebilir ki huzurlu bir ortamdan siyasi çalkantıların olduğu bir ortama evrilmiş bir toplum haline geldikleri için ahlak üzerine düşünülmeye başlanmıştır. Eş deyişle sistemli okulların ortaya çıkıp ahlak üzerine öğretiler geliştirmeye yoğunlaşmalarının sebebi, yaşanılan iyi ve huzurlu bir ortamdan iktidar ile birlikte birden bire buhranlı dönemlere geçilmesinin etkisidir.

Antik Yunan felsefesinde haz ve bunun zıddı olan elem kavramlarının mutlulukla doğrudan ilişkisi kurulmuştur (Akarsu 1982, 21). Diğer ekollerden farklı olarak hazcı bir ahlak anlayışı ve Tanrı'nın evrene müdahale etmediği bir varlık görüşüyle Epikürosçuluk, dogmatik bir anlayışla Stoalıların zıttı olan Septikçilik, Platon felsefesini din ile bağdaştıran Plotinos'un kurduğu Yeni Platonculuk ve bu çalışmada ayrıntılı olarak açıklayacağımız Stoacılık bu temel ekollerdir.

Stoa okulu mantık, fizik gibi konulara birbirlerinin ilişkiselliğiyle bütün olarak bakıp Stoa ahlakını oluşturmuştur. Stoalılar genel olarak felsefeyi; mantık, fizik ve etik olarak üçe ayırır. Stoa okulunda ilk okul Sokrates'in izlerini taşıyan Zenon'un kurduğu; ikincisi Roma döneminden etkilenen Platon ve Aristoteles'in izlerini taşıyan; son dönem ise yine Roma yaşamının pratik felsefeye etkisiyle daha çok ahlak, siyaset ve din ağırlıklı olan dönemdir. Stoa okullarının yanı sira Megara okulunun Zenon'la sona ermesi gibi Phaidon ve Elis-Eretria gibi okullar bu ekollerden etkilenerek sonunda Stoacılık içinde erimiştir (Arslan 2001, 37 vdd.).

Ahlaklı olmayı doğa felsefesiyle birleştiren Zenon, iyi yaşamı doğaya uygun yaşamakla özdeşleştiren bir insan felsefesi geliştirir. Çünkü dönemin çoğu filozoflarından farklı olarak, ahlakı ön planda tutarak ve doğa felsefesini destekleyerek günlük meselelere çözüm aramıştır. Zenon ve ardından gelenler için doğa felsefesi, toplumsal normların daha üstünde olduğu kabul edilen evrensellikle ilişkilendirilmiştir. Dolayısıyla kötü ve ahlaki olmayan kavramlar da, karşıdakinin tutumuna bağlı bir şekilde göreceli olarak hastalıklı zihin durumlarının yansıması olarak şekillenir. 
Şunu da belirtmek gerekir ki Stoalılar erdemli olmayı ve doğada ölümlü olmayı kabullenmeyi, dünyadan el etek çekmekle ya da dünya nimetlerinden faydalanmamakla bir tutmazlar. Dolayısıyla maddi başarılar elde etmek, zengin olmak, toplumsal statü kazanmak gibi çabaların olumlu tutumlara sebep olacağını düşünerek iç özgürlüğü engellemeyecek şekilde dünya meşelelerine eğilirler. Eş deyişle zengin bir insan aynı zamanda erdemli ise zenginlik bu durumda iyidir; çünkü hem kişiye hem de doğaya yararlı sonuçlar getirir.

Böylelikle doğaya yararlı sonuçlar getiren ve doğaya uygun hareket eden insan, aynı zamanda doğadaki her şeyin de kendine yararlı olmak için var olduğunu farkeder. Doğanın sesine kulak veren insan, yükümlülüklerin karşılıklı değişimiyle müşterek yararları gözetmeli, uzmanlık, iş ve yetenek sergileyip başkalarınınkinden yararlanarak insanların diğer insanlarla olan bağını güçlendirmelidir (Cic. Off. 12). Herkesin uyması gereken bu doğal yasa, aynı zamanda insanların doğa karşısındaki amacını göstererek, kendi ve çevresiyle uyumlu yaşamasını bildirir. Çünkü doğayla uyumlu olan insan, hiçbir konuda aşırılığı gözetmeden bedenini ve ruhunu dinginleştirerek, rasyonel süzgecinden geçirdiği doğa yasalarını kabul eder. Cicero'ya göre doğayla uyum içinde yaşayan insan iyi ve mutlu bir yaşam için amacını gerçekleştirme yolunda zihinsel rahatlamaya ulaşmış ve kaygılardan sıyrılmış bir şekilde bilge olma yolunda evrilmeye başlamıştır (Cic. Off. 72). Dolayısıyla doğayı ve kendini anlama noktasında bir araç olan felsefi düşünüş biçimi, ruhu olgunlaştırarak ölüm korkusundan sıyrılarak, kederin ve arzuların üstesinden gelebilmemizi sağlar. Ölüm üzerine korku ve kaygıları yenmede felsefeye yüklenen işlev, kabullenmeyle gelen bir ruhsal tedavi şeklindedir. Ruh sağlığını korumada felsefenin mantıksal düşünmeye sevk etmesi, aynı zamanda etik değerlere yönlendirir. Cicero'nun düşünceleri bilgi teorisinde şüpheciliğin ve ahlak bilincinin karışımıdır (Stokes 2018, 68). Cicero'nun ahlak felsefesine katkıda bulunduğu insan davranışlarının nasıl değerlendirilmesi üzerine düşünceleri, günümüze kadar geçerliliğini koruyarak süregelmiştir.

\section{Akıl ve İradenin Sağaltımı: Epiktetos}

Doğaya uygun bir tarzda yaşamanın önemini yine bir Stoalı filozof olan Epiktetos'ta da görürüz. Epiktetos, insanın nihai gerçeği olan ölüm kavramını küçük görerek aklı ve iradeyi kullanmanın yegâne yolunu felsefe ile ilgilenmekte bulur. Felsefe ile ugraşıyorum deme kendimi kurtar1yorum de (Toprak 1946, 4) ifadeleriyle bizi düşünce hastalığını iyileştirmek için felsefe eğitiminin alınması gerektiğine yönlendirir. Düşünce hastalığından kastı insan akıldan uzaklaştığı, akı1sız hareket ettiği zaman insanlığı kaybolur ve bir hayvan ortaya çıkar (Toprak 1964, 83) düşüncesine bağlı olarak geliştirmiş olduğu sağduyu felsefesidir. Bütün insanlarda normal bir duygu vardır ki ruhlarında temelli bir aksaklık olmayınca, kendilerine söylenilen her şeyi anlarlar. Bu güç bütün insanlarda eşittir. İşte sağduyu denilen budur (Toprak 1964, 83). Dolayısıyla insanın sağduyusunun farkına varmasıyla gelen ruhun olgunlaşması bir sağaltımsal metottur. Bu metotlara ise yine felsefenin bize sunmuş olduğu kavramları sorgulayarak kullanma, iradenin ne demek olduğunu bilme, etik değerlere yönelik bir yaşam tarzı geliştirme gibi bakış açıları kazanmayla ulaşılabilir.

Bir güzel söz söyleme sanatı varsa, bir de güzel anlama ve dinleme sanatı vardır ki buda felsefedir (Toprak 1946, 96). Epiktetos, insanda olmas1 gereken değerlerin ancak felsefe ile anlaşılacağına ve felsefeye bir araç olarak yol gösterici yanıyla bakar.

Hekimlik sürekli hastalığı olanlara hava değiştirmeyi salık verdiği gibi, felsefe de böylece kökleşmiş alışkanlıkları olanlara yer değiştirmelerini salık verir. Çünkü bu alışkanlıkların kuruluşunu sağlayan hava onları güçlendirmekten başka bir şey yapmaz (Toprak 1946, 112).

Felsefeyi bir yaşam tarzı olarak görüp faydalanmak isteyenlerin iradelerini de bu yönde kullanmaları gerektiğini söyleyen Epiktetos, ancak bu sayede mutluluk yoluna girilebileceğini belirtir. Çünkü bu sayede beklentiler askıya alınır, isteklerin sonsuzluğu bir doyumsuzluk 
getirmez, başına gelinmesinden korkulan durumlara düşülmez. Mutluluk yolunda düşülen karamsarlığın bir sonucu olarak hayattan vazgeçme durumlarına güzel bir cevabı vardır. Intihar vakalarının sağaltımsal çözümlemerini açıklamaya girişildiğinde böyle bir değerlendirme kanımızca kayda değerdir. Epiktetos kitabında aç kalarak intihar etmek isteyen arkadaşına sorar:

- Neden?

- Karar verdim.

- Bu bir sebep olamaz. İnsan bütün verdiği kararları tatbik etmemelidir, yalnız doğru basiretle hakkaniyetle ve makul olarak verilen kararları tatbik etmelidir. Bizi neden iyi bir dosttan memleketi iyi bir vatandaştan mahrum etmek istiyorsun? (Toprak 1946, 7).

Görüldüğü üzere Epiktetos, felsefi düşüncelerin tutarlı bir şekilde yaşama empoze edilmesiyle günlük kaygılardan, hayal kırıklıklarından, korkulardan ve arzulardan sıyrılarak yine tam da yaşamın içinde ondan uzaklaşmadan nasıl başa çıkılabileceğinin ve eğer baş edilemiyorsa nasıl kabullenileceğinin felsefesini sunar. Fakat burada bir uyarıda da bulunur:

Bizi ezen şey, felsefeyi dudaklarımızın ucu ile tadar tatmaz, hemen lider rolü oynamaya çıkmak, başkalarına faydalı olmayı düşünmek ve dünyayı yeniden düzeltmek isteyişimizdir. Hey dostum! İlk önce kendini düzelt. Ondan sonra insanlara, felsefenin yola koyduğu bir adam göster. Soydaşınla; yiyip içerken, gezip dolaşırken kendi örneğinle onları aydınlat (Toprak 1946, 146).

İşte insanın ilkin kendine yönelerek sağaltması ile bunu felsefi bir zeminde yapamayanın arasındaki fark budur. Çünkü kendini sağaltan birey, olgunlaştıkça durumların farkında olarak diğer insanlara yardım edebilecektir. Elbette ki bu sancılı bir dönemdir ve tıpkı ağır bir hastalığın iyileşmesinin uzun soluklu ve ağır geçmesi gibi sağaltıma yönelen kişi, diğerlerine salık verdiği metotların o kişide şiddetli ağrılara neden olacağının farkındadır. Dolayısıyla sağaltan kişi, aynı zamanda telkin edici durumundadır.

Epiktetos'a göre özgürlük, elimizde olmayan şeyleri değiştiremeyeceğimizin farkında olmamızla başlar. Eşdeyişle insanın gücünü aşan durumlarda müdaheleyi dış dünyaya yapamasak bile bu duruma katlanma özgürlügümüz vardır. $O$ halde insan sınırını aşan durumlarda özgür iradesiyle kontrol edebileceği tek şeyin kendi olduğunu bilmelidir. Kastedilen bu özgürlük doğaya ve dış dünyanın getirdiklerine karşı bir yapıda değil, aksine iç dünyamıza yönelik eş deyişle duygulara, arzulara boyun eğmeyen rasyonel yapıda bir iradeyi gösteren özgürlüktür. Epiktetos'a göre insanlarla ilgili konular bireyin kendi iradesi dışında olduğu için bunu dert edinmek anlamsızdır (Toprak 1946, 155). Fakat bu yaklaşım, dışarıdaki dünyaya kayıtsız olmayı değil, kabullenmeyi ve anlamaya çalışmayı göstermek içindir; aksi halde bir boş vermişlik durumuyla birey toplum içerisinde umut etmeyen, katkı sağlamayan, iletişim kurmayan, umarsız biri olarak mutsuzluğa gömülür.

İnsanları kederlendiren eşya ve hadiseler değil fakat bunlar hakkındaki fikirleridir. Mesela ölüm bir felaket değildir; eğer bir felaket olsaydı Sokrates'e de böyle görünecekti fakat ölümün bir felaket ve şer olduğu hakkındaki kanaat asıl felaket budur (Toprak 1946, 13).

Epiktetos metinlerinin analizinde felsefesini tamamen irade kavramı üzerine kurduğu görülmektedir. İnsanın kararının iyi ya da kötü olması, tercihleri, düşünce iradesinin kendi elinde olduğunun insanın iradesi olan bir varlık olduğunun göstergesidir.

İrade ve aklın sağaltımsal tavrını yaşam felsefesiyle bütünleştiren bir yoksul, yoksulluğun da tadını çıkararak ulaşamadığı arzulara kayıtsız kalarak kendine yeter olacaktır ve iyiliksever tavırlarıyla kendiyle ve doğayla barışı olduğunu gösterecektir. Günlük meşguliyetlerin gelip geçiciliğine aldırış etmeden özgür yaşamanın tadını çıkaracaktır.

Hastalık vücut için bir engeldir. Fakat irade zayıf olmadıkça engel değildir. "Ben topalım"; 
Bu vücut için bir zaaftır fakat iraden için asla bir zaaf değildir. Başına gelecek her kaza için aynı şeyi düşün o zaman bunların başka bir şeye mani olduklarını fakat sana asla mani olmadıklarını anlayacaksin (Toprak 1946, 14).

Günlük hayatta karşımıza çıkabilecek her türlü hadiseler için öğütler veren Epiktetos, beden terbiyesi, irade, dostluk, eğlencenin sınırı, mevki sahibi birinin kapısını çalmak gibi başkalarının ve kişinin kendine hürmet etmesi, saygınlık kazanmak, doyumsuzluk gibi kavramlar üzerinde düşünerek bir sağaltımsal metot olarak Stoa yaşam tarzlarına yeni bir bakış açısı kazandırmıştır.

Yürürken bir çiviye basmama, ayağının burkulmamasına imtina ettiğin gibi, varlığının en esaslı tarafının yani seni idare eden aklında çarpılmamasına dikkat et hayatımızın her hareketinde bu kaideye riayet edersek her şeyi daha emniyetle yapmış oluruz (Toprak 1946, 32).

Dolayısıyla yaşamda düşünme sınırlarının ötesinde hazır bulunuşluğun insanı birçok yönden koruyacağı gibi aklını özgürce kullanmanın, duyguların esiri olmadan varlığını sürdürebilmenin, pratikte insana katacağı sağaltımsal etkiyi de bir metot olarak çıkarsayabiliriz.

\section{Kabullenme ile Erdem: Seneca}

Lucius Annaeus Seneca felsefe ile ölüm ilişkisini, felsefe ile birlikte anlam kazanan yaşam arasındaki ilişkiye benzetir : Bilge insan ölümü yüreklilikle kabul eden kişidir (Sen. Cons. 134). İnsan doğanın bir kanunu olarak doğup ölmeyi kabul ettiğinde, kabullendiğinde mutlu olma yolunda ilk adımını atmış sayılır. Seneca, Teselliler adlı eserinde yaşam ile ölüm arasındaki anlamlı yolda felsefenin rehberlik etmesine izin veren insanın kendi için doğru olanı yapmış olacă̆ını ifade eder.

Sağlıklı bir zihne sahip olmak için kendini felsefe ile tedavi eden kişi Seneca'ya göre, hastalıklı düşünceler veya hüzünlü durumlarda bile kederli olamaz. Bilge için bu durum, felaketlerde bile ortaya çıkmaz. Bilge üzüntüyü kabul etse de kötülüklerle başa çıkmak için savaşmak zorundadır (Sen. De Clem. 73). Dolayısıyla erdemli davranan kişi, yaşama dair mücadelesinde felsefeyi bir araç olarak kullanır. Ruhu eğitme sanatı olarak felsefeyi pragmatikleştirme, genel olarak Stoalı filozofların temel argümanı olarak burada da karşımıza çıkar. O halde bu dünyaya geldikten sonra yapılması gereken şey, dünyayı benimseyerek ve karşılaşılan zorlukları tevekkülle kabul ederek yola devam etmektir. Böylelikle de insanın yaşadığı dünyayla anlamlı bir ilişki kurabilmesi sağlanmış ve yaşamın ne demek olduğu doğru anlaşılmış olur.

\section{Felsefi Öğ̈̈tler: Aurelius Antoninus}

Marcus Aurelius Antoninus, bir Stoalı olarak karakteri düzeltmeyi ve gözetmeyi gereksinme bilincine varmış olmayı, dikkatle okumayı ve üstünkörü bir anlayışla yetinmemeyi; gevezeleri hemen onamamayı gibi verdiği ögütlerde aynı zamanda felsefi yaşam tavrını da açıklamış olur. Doğaya uygun yaşamanın anlamının kavranması ve her çeşit insanla uyuşma sanatının öğrenilmesini insanın mutluluk yolunda yapması gerektiğini düşünen Antoninus, insanın her sabah uyandığında öncelikle kendine hatırlatması gereken sağaltımsal sözleri salık verir. Bir patavatsızla, bir iyilikbilmezle, bir küstahla, bir kalleşle, bir geçimsizle karşılaşacağım. Tüm bu kusurlar bu insanları başına, iyilikler ve kötülükler konusundaki bilgisizliklerinden ötürü gelmiştir (M. Aur. Medit., 6) Her şeyin bir bütün olduğunu dışlamanın bir fayda sağlamayacağını düşünen her Stoalı gibi Antoninus da her insanın birbirine ihtiyacı olduğunu ve elbirliği etmek için doğmuş bulunulduğunu düşünür.

Bir başkasının ruhunda olup bitenler üstünde hiç düşünmemiş olmaktan ötürü mutsuz bir insan görmek, kolay değildir. Kendi öz ruhlarına ilişkin devinimlerin bilincine varamayanlara gelince, bir gerekliliktir onların mutsuz olması (M. Aur. Medit. 6).

Böylelikle yaşamın karmaşasında felsefe ile içimizdeki bilgeliğin hem olumsuzluklardan uzak hem de zevk ve acılardan ayrı durmasına; yalanlarla bir eylemde bulunulmamasına; başka- 
larının yaptıklarına bağlanılmamasına sonuç olarak da başa gelenin kabul edilmesine inanan Antoninus, böylelikle bir rehberlik yapmış olur. Felsefenin bilme ve anlama işlevinin çok daha ötesinde yaşamda yol gösterici bir rehber olarak görülmesi, bilindik felsefe kavramı tanımlamalarından farklı bir konuma yerleştirerek iyi, mutlu ve sağlıklı bir zihin için bir araca dönüşmesine sebep olmuştur.

Felsefeyi bir yaşama sanatı haline getiren Antoninus, Meditasyonlar'da karşıdakiyle bir diyalogda dengeli bir anlayış oluşturmak, konuşma eşitliğine firsat vermek ve ifade özgürlügünde bulunmak her şeyden önce konunun özgürlügünü onurlandırır. Tutarlılık göstererek felsefi açıdan tek düzeliğe karşı iyi olmak, başkalarına karşı cömert olmak, arkadaş sevgisine güvenmek, tanışanlarla dürüst ve açık olmak (M. Aur. Medit. 6) gibi belli kavramları bir metot olarak sunar.

Antoninus, insanın yaşadığı süre zarfında elinden geldiğince iyilik insanı olması gerektiğini düşünür. Bu şekilde de doğanın bütünselliğinden insanın başına geleni hoş karşılayıp davranışlarında doğru ve iyi dilekli olmakla yetinen iyilik insanının, yaşamının ona uyacağını doğanın onun yanında olacağını aynı zamanda da üzüntüye yönelten her olayda, bunun bir terslik olarak görülmesinden ziyade buna soyluca katlanmanın mutluluk getireceğini düşünür. İşte insanın doğasına uyumu felsefe aracılığıyla olur. Akıllı bir varlık olan insan bu konuda düşünerek kusurlarını kavramaya çalışabilir (M. Aur. Medit. 33-50) gibi çeşitli öğütlerle Antoninus, yaşamda sağaltımsal pratiği salık vererek aşağıda değineceğim metotları oluşturmamızda bize yol göstermiş olur.

Kişisel yaşam tarzlarıyla bütünleşmiş ahlak anlayışları geliştiren Stoalılar, aynı zamanda toplumsal olana ilgi duyarak umutsuzluk, ölümden korkma, günlük meşguliyetlerde endișe etme, varoluşsal kaygılanma gibi kavramlar üzerinde düşünerek yaşamlarına öğretilerini katmaya çalışmışlardır. Bu tavırlarıyla Stoacılara aşırı ağırbaşlı insanlar olarak bakılıyordu (Hadot $2012,146)$. Stoa ahlak felsefesinin temelinde elbette ki kendi dönem ve öncesi filozoflarının da etkisi olmuştur. Genel olarak düşünüldüğünde ahlak yasaları içerisindeki dile getirilen konuların bir evrensel nitelik taşıyor olması, her çağda benzer düşüncelerin ele alınması, kavramlara aynı perspektiften bakılması ahlak kavramının genel geçer olmasının ve her çağda benzer düşünülebilmesinin gerekçeleridir. Dolayısıyla yüzyıllar sonra bugün bile aynı kavramlar üzerinden düşünülüp aynı sorunlar tartışılabilmektedir. Birbirine eklemlenerek günümüze ulaşan belli kavramların sağaltımsal faydasallığı düşünüldüğünde, özellikle tüm Stoalıların genel ortak kayg1 duydukları ve üzerine düşündükleri kavramlardan yola çıkarak Stoa sağaltım metotları oluşturulabilir.

Kozmik düzen, insanın etik davranışları için sadece bir bağlam değil, aynı zamanda model de sağlar. Chrysippus, doğal olaylardan edindiğimiz deneyimler doğrultusunda yaşamamız gerektiğini, çünkü bireysel doğalarımızın evrenin doğasının bir parçası olduğunu söylemekteydi (Kenny 2018, 315). Denilebilir ki genel olarak Stoalı filozoflar dünya, doğa ve insan ilişkisindeki teleolojik yaklaşımlarında bir amacın ve düzenin olduğunu varsayarak iyi, kötü ya da insan olmayan tüm varlıkların bu düzen içerisinde bir uyumun parçası olduğunu kabul etmişlerdir.

Stoalı filozoflar, etik teorilerinden yola çıkarak tıp alanından da faydalanabilmişlerdir. İlkin Stoik normların örtük bir metaetik ile insan doğasının ve çeşitliliğinin şematik anlatımına yönelindiğinde, bu konunun tıp biliminde de norm belirleyici tartışmalara paralel olarak yürüdüğü görülür. Hem Stoik felsefe hem de tıp bilimi insan türünün genel özelliklerinin soyut ön tanımlamalarından yola çıkarak belirli bir ortamda belirli bir insana, bireye fiziksel ve ruhsal sağlık konusunda yardımcı olmaya çalışır (Becker 2003, 221). Dolayısıyla Stoalı filozofların öğretilerinden yola çıkarak günümüz insanına yaşamında büyük etki yaratacak sağaltım metotları oluşturmak kaçınılmazdır. Bu metotları günümüze taşırken, yine belirtmek gerekirse, felsefi 
uygulama sadece bireysel değil, aynı zamanda şirketler, kuruluşlar, derneklerin ilkelerini bulma girişimlerinde destekleyicidir. Felsefe reçete yazılacak tedavi içermez. Biri hastaysa doktora gitmelidir (Achenbach 2010, 17). Dolayısıyla sağaltımsal çalışmalar tıbbi yarar gözetmenin ötesinde, tedavi ya da kriz noktasına gelmeden önce yürütülmesi gereken bir öğretiler bütünü olarak felsefenin içsel perspektifinden bakmayı gerektirir. Dolayısıyla bu, birey dışında kuruluşlarda da uygulanabilir. Bir uygulamalı felsefe olarak, şirket ve organizasyon danışmanlığı uygulamalı etik olarak da görülebilir.

\section{Stoa Felsefesiyle Sağaltım Metotları:}

Daha iyi nasıl anlamlı bir yaşam sürdürebiliriz? Bu yaşam nasıl daha yaşamaya değer olur? gibi sorulara etik bakış açısıyla cevap arayan insan, hep doğanın bütünselliğinde kendini bulma arzusu içindedir. Aynı zamanda toplumsal bir varlık olarak insanın doğa ile ilgisini kaybetmeden kendini var etme çabasında bulunmasıyla Stoa felsefesinin kastettiği ahenk yakalanmış olunur. Bu ahenk mutlu olmak değil, mutlu olma çabasıdır. Felsefi danışmanlık ya da sağaltımı kendi yaşam tarzlarıyla en iyi açığa çıkaran filozoflardan olan Stoalı filozoflar Antik felsefenin ruhsal ve zihinsel bir uygulama olduğu yaklaşımını benimserler (Filiz 2018, 34). Stoa felsefesini bu açıdan incelediğimizde sekiz sağaltım metodunun çıkarsanabileceği kanaatindeyiz.

\section{Doğa ile bütünsellik ilişkisi (Phantasia kataleptike)}

İnsanın doğa ile bütünselliği ilişkisi, Stoacı filozofların öncesinde de incelenmiştir fakat Stoa düşüncesini benzersiz ya da farklı kılan unsurlar vardır. Öncelikle Antik Yunan felsefesinin ilk dönemlerinde ele alınan temel konu, doğanın gizemini çözmeye yöneliktir. Bu konular evrenin kaynağı, doğanın nereden geldiği, varolanların nereden ve nasıl türediği üzerine olduğu düşünüldüğünde, bir doğa felsefesi karşımıza çıkar. İlk doğa filozofları, her ne kadar özgün ve bağımsız olarak felsefi düşüncelerini geliştirmiş olsalar da doğayı algılamada daha çok oluşların ardındaki değişmez olanı aramışlar eş deyişle görünüşün ardındaki birliğe yönelmişlerdir. Dolayısıyla arkhe arayışına yönelen bu filozoflar doğanın evren ya da Tanrı ile ilişkisine odaklanmışlarken Stoalı filozoflar ise gündelik yaşam içerisindeki insana yönelik, doğa ile insan ilişkisinde bir bütünsellik arayışında düşüncelerini geliştirmişlerdir. Bir görünüş ile gerçeklik ayrımı yapmaktan ziyade doğaya ilişkin açıklamaları yine doğadaki insanın davranışları çercevesinde aramışlardır. Bu yüzden kozmik bir düzen geliştiren İyonya Okulu ya da maddenin ötesinde bir form ve bir sayı sistemi geliştiren Pythagorasçı Okuldan daha farklı olarak doğayı ele alan Stoalı filozofları önemli kılan bir diğer özellik ise kendi ekolleri çerçevesinde geliştirdikleri sistemin tamamen insanı doğanın içine katarak uygulamalı felsefe yapmalarıdır.

Platon her şeyden önce erdem ve iyi kavramlarını tanımlamakla ve insanlara mutlu olmanın yolunu öğretmekle uğraşmıştır (Akarsu 1982, 103). Platon ve Aristoteles ile gelişen insan nedir ve ahlak sorunlarının önemi, Stoalılar ile birlikte insan ve doğanın ortak kavranılmasına yönelerek bir senteze ulaşmışlardır.

Stoa fesefesindeki gündelik yaşama sağaltımsal bakış açısıyla yaklaşmak için ilkin bütünsellik algısının ne demeye geldiğini açıklamak gerekir. Öncelikli olarak doğanın bir parçası olduğumuzu kabul etmeli, onu anlamanın tek yolunun yaşamla içiçe olmak, yaşamdan kaçınmamak ve onu deneyimlemek olduğunu bilmeliyiz. İnsan algılarını açık tutarak, algıladığının ruh ile doğru kavranmasını sağlamalıdır. Burada bir kavram karşımıza çıkar: phantasia. Zenon phantasia'yı ruhtaki bir intiba olarak, ruh tarafından kavranılabilir (katalepsis) ve kabul edilebilir şekilde dışarıdan gelen itim olarak tanımlar (Peters 2004, 288). Çünkü gerçeği bize sunan dış dünyayı algılamanın ruh ile birlikte kabul görmesi sağaltımsal bir metottur. Dışdünya ile kurduğumuz bağda deneyimler, bilgiye dönüşür. İşte phantasia kataleptike, Stoalılarca bu deneyimler anlamında kullanılır. İnsan bu deneyimlerle değişip gelişir. Çünkü Stoalı filozofların 
doğa ile insan arasındaki ilişkiyi hesaba katarak kurdukları ahlak anlayışında, doğaya uygun yaşamak ve doğa ile bir bütün olduğumuzu kabul etmek temel argümandır. Denilebilir ki doğaya uygun yaşama prensibi Stoa ahlak felsefesinin önkoşuludur. Stoalıların kastettiği doğa, hem metafiziksel anlamdadır hem de daha yoğun anlamıyla insanın ontolojik ilkesi olarak doğa yani fiziksel bir doğa anlamındadır.

\section{Kendine yeterli olma (Autarkeia)}

Sokrates'in kendini bil düsturundan yola çıkılarak; kendini bilmenin kendine yeterli bir yaşamla bağlantılı olduğu sonucuna varan Stoalı filozoflar da felsefelerinde bilgeliğe büyük önem verirler. Stoalılar autarkeia'yı erdemin bir niteliği olarak görürler (Peters 2004, 56). Dolayısıyla bilgece yaşam kendini bilmekle yola çıkıp, doğaya uygun yaşayıp öncelikle kendi yaşamını anlamlandırmakla başlar. O halde bilmek aynı zamanda bireyin kendine yetebilmesi ve bu doğrultuda yaşamını sürdürmesi anlamına gelir. Erdemli insanın temel niteliklerinden biri olan kendi kendine yeterli olma, eşdeyişle autarkeia kavramı, Stoalıların genel olarak yaşam felsefesi pratiğinde görülmektedir. Anlaşılacağı üzere burada insanın kendini tanımasının, kendiyle bir iç yolculuğa çıkmasının amacı yaşam içerisinde huzuru bulma arzusudur. Bu iç yolculuk için doğayla yalnız kalan insan, dış dünyanın günlük meşguliyetlerinin, kaygılarının farkına varıp bunlardan soyutlanarak iradesini görmeye çalışır.

\section{Erdemli ve iradeli yaşamaya çalışmak (Apatheia)}

Stoacılar için kurdukları felsefeyi bir yaşam tarzına çevirmek önemlidir. Erdemli bir yaşamı, kuram eylem bütünlüğünde sergilemek; zihnin sağlıklı olması kadar bedenin de sağlıklı olmasını gerektirir. Olumsuz duygulardan kurtularak eş deyişle apatheia yaparak, mutluluk yoluna girmekle iradeli yaşamak mümkün olur. Dolayısıyla erdemli düşünmenin yanı sıra erdemli olmayı amaç edinecek bir iradeye sahip olmak önemli bir sağaltımsal metottur. Genel olarak Stoalılara göre, insan için ayırıcı bir özellik olan iradeli davranmak huzurlu bir zihin durumunu temsil eder. Sağlıklı ve huzurlu bir zihin durumu ise mutluluk yolu açısından ruhen ve bedenen bütünlüğe ulaşmış olmayı gösterir. Kelime anlamı etkilenimsizlik, duyumsamazlık, duyarsızlık olan apatheia, Stoalılarca günlük oyalanmalara kapılıp gitmeden iradeli yaşamanın ne demeye geldiğini anlatır. Stoacılar, kendilerinin apatheia versiyonunu duyarsılıktan ya da düpedüz ahmaklıktan ayırt etmek için bir hayli ter döktüler (Peters 2004, 37). Bu bakımdan "apatheia pratiği”ni böyle okumak insanın karşısına erdemli davranmanın bir yolunu çıkarır.

\section{Kaygı ve tasaların üstesinden gelmek (Ataraksia)}

Staocıların doğaya karşı dikkatliliği ve ruhsal bilincin en yüksek düzeyde tutulması fikri, kişide bir kaygı yaratır. Bu kaygı doğayla uyum içinde yaşamanın koşullarına odaklanır (Filiz 2018, 35). Duyumsanan bu duyguyu tanımlamak ve betimlemek aslında ruhsal bakımdan iyileştirici bir metottur. Genel olarak Stoa metin okumalarında başlıca metot, kayg1 verici düşüncelerden kurtulmak için öncelikle insanın duygusal sorunlarını ve davranışlarını anlamaya çalışmakla başlamaktır. Aşırı coşkun duyguları kontrol edebilmek, hayatı daha dingin yaşamanın getireceği huzurla günlük yaşamdaki kaygı durumlarını minimize etmeyi sağlar. Fakat kastedilen olup biten herşeye kayitsız kalınabilmesi gerektiği değildir. Ataraksia, huzursuzluk yokluğu, denge, ruhun dinginliği, soğukkanlılık, tutkulardan arınmışlık, iç huzur (Peters 2004, 54) anlamlarında kullanılır. Önemli olan yaşam içerisinde karşılaşılan kontrol edilemeyen ya da değiştirilemeyen durumlar karşısında dövünmek yerine, bu durumu kabul ederek olumsuz bir tavır takınmadan daha farklı bir bakış açısıyla değerlendirebileceğimizi görmektir. İşte kendisini sıfır noktasında hisseden bir Stoalı'nın yaşadığı durumu ataraksia ile özümsemesi kaygılardan sıyrılarak zihin sağlığını kazanması ruh dinginliğinin en genel yoludur. 


\section{5. Ölümden kaçmamak (Athanatos)}

Athanatos, Stoacılarda yıldızlara özgü bir tür göksel ölümsüzlüğü (Peters 2004, 55) sembolize eder. Bu bağlamda ölümü seçip vaktinde ölmek erdemdir. Yaşamın kısalı̆̆ı, yaşlılı̆̆ın kaçınılmazlığı söz konusuysa, o halde bize verilen süreden olabildiğince faydalanmak gerekir. Her Stoalının belki de en ortak noktası olan ölüm kavramı, aslında yaşamın içinde olup her daim kendini düşündürmeye yöneltmiştir. Ölüm korkusu nedir sorusuyla bizi karşı karşıya getiren ve çeşitli çare arayışlarına yönlendiren Stoalıların bir diğer kazanımı da budur.

Ruh ve zihin gerilme ve gevşeme arasındaki gelgitlerde varoluşun sınırlarının keşfedilmesine yardım eder. İnsanın neyi ne kadar, nasıl ve hangi koşullarda öğreneceği, varoluşunun bu sınırlarını keşfettikten sonra açıklık kazanır (Filiz 2018, 35). Ontolojik bir tutumla filozofların ölüm hakkındaki yaklaşımları varoluşsal olarak kendini tanımayla ilişkilendirilir. Düşünsel malzemeler sağlayan bu tavır, korkuyu yenmeye muktedir bir metot olarak karşımıza çıkar.

\section{Filozofça davranmak (Phronesis, logos)}

Yaşam içerisinde teknik bilginin ötesinde derin felsefi anlamlar taşıan sorulara cevap aranıldığında phronesis kavramı karşımıza çıkar. Cevap aranılan bilgi, phronesis, eş deyişle bilgelik, pratik bilgelik, sağgörü, engin ve incelikli düşünme, yücegönüllülük ve akıl sağlamlığıdır (Peters 2004, 294). Peters'e göre Stoac1lıkta merkezi bir rolü olan phronesis, filozofça davranmak konusunda bize ipuçlarını sunar. Bilgece düşünmeye yönelten bu kavram aynı zamanda duyguları kontrol altına alarak analitik düşünme ve eyleme tarzını bir yaşam biçimi haline getirmenin verdiği huzurun sembolüdür.

Antik Yunan dünyasında en çok kullanılan kavramlardan bir diğeri olan logos, Stoalı filozofların da felsefelerinde önemli bir yere sahiptir. Doğa, bir bütün olarak logos tarafindan düzenlenip şekillenerek tıpkı insan gibi varlığını korur. Logos kavramına Stoacılarca bakış açısı, Herakleitos'un düzen formuyla, maddi olmasıyla ilgilidir. Bu kozmik düzen, birçok yönde gelişip açılım kazanır: bir birlik olduğu için, kozmik duygudaşlık ve doğa yasası teorisinin ve doğaya uyarak yaşamak şeklinde ifade edilebilecek etik buyruğun temelinde yatar (Peters 2004, 210). İnsan akıllı bir varlık olarak yapıp etmelerini seçmelidir. Dünyanın bütünselliği algısı, dünyayı anlamak ve kendini anlamlı kılmak için akıllı olan doğanın yasalarına uymak gerektiği düşüncesini her Stoalı filozofun temel düşüncelerinde görmekteyiz. Doğa ile ilişkisinde insan kendinin farkına varırken, logos düşüncede kendini açığa çıkarır.

\section{Felsefi eylem (philosophia, paskhein)}

Paskhein, etkilenmek ve edilgin halde olmak anlamlarına gelir. Stoacılıkta edilgin olan maddeyle, etkin olan logosla özdeşleştirilir (Peters 2004, 280). Stoalıların genelinde görülen felsefe etkinliğini bir eylem olarak davranışa çevirme eğilimi, yaşamın sağaltımı açısından en değerli tutumdur. Eğer yaşamda yegane kaygımız mutlu olmaksa, bu yolda gitmek için erdemli olmak gerekir. Erdemli olmayı doğaya uygun yaşamakla örtüştüren Stoalılar için doğaya uygun yaşamak ise hem doğal bir yaşam sürdürmek hem de akılsal ve eylemsel olarak doğanın yasalarıyla uyumlu olmak anlamına gelir. İşte bu pratikler birliği tüm Stoalılarda felsefi eylemi ortaya çıkarır.

Stoacılar felsefeyi bir kez daha teorik olan kadar pratik olanı da kucaklayacak şekilde genişletmişlerdir. (bk. Cicero'nun philosophia'yı ars vitae (yaşama sanatı) olarak tanımlaması) (Peters 2004, 291) Doğanın en bilinçli varlığı olan insan, aynı zamanda kendinden üstün olan bir bilince bağlıdır. Bu bize doğanın karşısında insanın edilgin halde olduğunu gösterir. Böylelikle üstün bilinçten pay alan insan, genel düşünceleriyle ve deneyimleriyle bu sistemi kavrayarak sağlıklı düşünceye sahip olur. 


\section{Asıl değerli olanı bilmek: proegmena, apoproegmena, axia, apaxia}

Stoacılar vasat şeylerin hepsinin aynı düzeyde olmadıklarını düşünmekteydiler. Bazıları seçilmeye değerdir (proegmena), bazıları seçilmeye değer değildir (apoproegmena). Daha da önemlisi, bazıları doğaya uygunken bazıları doğaya aykırıdır. Doğaya uygun olanlar bir değer (axia) taşırken, doğaya aykırı olanlar değersizdir (apaxia). Değerli olan şeyler arasında yetenekler ve beceriler, sağlık, güzellik ve zenginlik gelir (Kenny 2018, 317).

$\mathrm{O}$ halde değerler arasında bir ayrım yapılmalıdır. Yaşamak, dünyanın faydası uğruna bir görevin olduğu süresince bunu bilerek yaşamak gibi doğru kavramlara verilen değer, bütünsel bir iyiyi ifade eder. Bu tarz değer verme aynı zamanda kişinin sağaltım ya da mutluluk yolunda olduğunun göstergesidir. Bunun karşısına koyabileceğimiz nesnesel değer, şöhretli olmaya verilen değer gibi, insanın dünyadaki anlamı üzerine yanlış bir yönelme olacağından erdemli bir eyleme yönlendiremeyeceği gibi mutluluğa da erdiremez. İnsanın doğasında olmayan hazcı yaşama arzusu, şan şöhret hırsı gibi kavramlara duyulan değer verme, bilgi ile eylemin birliğine de aykırı olduğu için Stoa öğretisinde kabul görmemiştir.

\section{Sonuç}

Stoa felsefesinin bugüne etkisini daha iyi anlayabilmek için, uzun bir dönem yaşayan bu felsefe okulunun bileşenlerinin sağaltımsal yorumlarını incelemek yerinde olacaktır. Son değerlendirme, mutlu olma yolunda yapılacak ahlaki davranışların sağaltımsal yöntemine ilişkindir. Stoa felsefesi pratik hayattaki insanı değerlendirmede araç olarak ahlaki davranışları kullanır. Bu eylemlerin sağaltımsal başarısı da insanın kendinin ve dünyasındakilerin mutluluğunu bir bütün olarak ele alması ve olumsuz hastalıklı düşünceleri bertaraf etmesidir. Dolayısıyla hastalıklı düşünceleri bir tedaviyle iyileştiren söz konusu fikirleri, bu sağaltımsal tutum, aynı zamanda erdemli bir hayatın olanaklılığını da ortaya çıkarır.

Yukarıdaki bölümlerde değindiğimiz üzere, Stoa felsefesini değerlendirme biçimine yönelik temel argümanlar irade, erdem ve mutluluk arasındaki ilişkidir. İnsanın yapıp etmelerine yönelik dış dünyaya olan tavrında iradeli davranmasıyla mutluluk yolunda ilerleyebileceği ortaya konmuştur. Bu ilişki insanı diğer canlılardan ayırarak doğada ona özel bir yer verir. Yaşamı anlamlı kılan bu ilişki, çağımıza kadar ulaşan, akla ve iradeye dayalı teorik bilgiyi öne çıkaran bir yapıdır.

Stoa felsefesine yönelik önemli bir nokta da dünyayı ve içindekileri bir bütünsellik içerisinde görüp her şeyi doğayla bir olarak kabul etmektir. Yaşamın temel argümanı olan hayatın içine, şimdi ve buradaya taşınarak aynı zamanda doğadaki tüm canlılarla ortaklığımız olduğunu kabul ederek bir bakış açısı kazanmak gerektiğidir.

Sonuç olarak, Stoa üzerine etik çalışmalar bir yandan insanın kendi sağlıksız düşünce yapısından kurtulma uğraşına bir yandan da hayvanlar ve bitkileri de kapsayan tüm canlılar için evrensel ahlaki kurallar ve ilkeleri oluşturma uğraşına nail olmak için bir yol gösterici mahiyetindedir. Çünkü yaşamı anlamlandırmamızı sağlayan ahlaksal kavramlar, patolojik bir durumun oluşmasında mutsuzluğa ve kötülüğe sürükleyen her şeyin aslında doğadan kopuş ve yabancılaşmayla ilişkisinde ortaya çıktığını göstermektedir. Yapaylıktan kurtularak ruhsal dinginliğe erişilir. Dolayısıyla bir Stoalı için insan, yaşamı olduğu gibi kabul eden, karşısına çıkan hezeyanları onaylayan, çağının problemleriyle yüzleşerek kaygılara boğulmayan, aynı zamanda iradesini kullanan ve ürettiği değerleri koruyan bir varlıktır. Günlük temaşaya sırtını çeviren insan, sıradan bir hayatı seçerek, eş deyişle doğaya yönelerek mutluluğu geri kazanır. O halde insan, doğal düzeninin işlerliğinde zaten ruhsal dinginliği sağlanmış bir varlıktır. Bu bağlamda erdemli olma potansiyelini açığa çıkaran insan gerçek anlamda özgür de olur.

Etik temaları olan Stoalıların yaşam öğretileriyle felsefeye ve diğer bilgi dallarına yaptıkları 
katkılardan söz etmek gerekirse, insan doğasının önemli bir yönüne dikkat çektiği ve bu yönüyle çağımız için özel bir anlam taşıdığı söylenebilir. Dolayısıyla tüm insanlığı ilgilendiren kavramlar üzerinden bir yöntem geliştiren Stoalılar, bizi bir mutlu olma-etme sorumluluğuna davet eder. Bu yüzden Stoalıların yaşamı yorumlamaları sağaltımsal bir perspektifle okunmalıdır.

İlk çă̆ felsefesinin zihin ve psikoloji iyileştirme özelliği, kendinden sonraki tüm tarihi etkileyen bir serüven olmuştur. Bu özellik ise en çok Stoalı filozoflarda kendini gösterir. Öğretilerin insan yaşam tarzını şekillendirme, aşırı güdüsel eğilimlerin, çilekeşliğin, kaygının, günlük endişelerin, ölüm korkusunun getirdiği buhranlardan arınarak, bu tür duyguları inkar etmeyerek kabullenip yaşam yoluna devam etme eğilimi, daha sonra sadece Stoa ekolüne bağl1 kalanları değil, tüm felsefe ekollerini kapsayan bir bakış açısı kazandırmıştır. Nitekim günümüzdeki felsefi terapi çalışmalarını oluşturan bu eğilimdir.

İlkçağ felsefesinden günümüze kadar insanı anlamaya ve tanımaya çalışan filozoflardan yola çıkarak, insanın tek boyutlu açıklanamayacak kadar derin bir varlık olduğu görülmüştür. Yaşamsal pratikler dünyasında insan, kendi yaşamını kurgulamak için felsefi sağaltım yapmaya muhtaçtır. Çünkü görürüz ki ancak bu şekilde kendini ve çevresini sağlıklı bireylere dönüştürebilir.

Niyetimiz kanımızca oluşturduğumuz sekiz farklı metodu göstererek, Stoalılardan hareketle en değerli soru olan "nasıl yaşamalı?" ve "nasıl düşünmeli?" sorusunun karşısında merakı yeniden uyandırmak, bu hazzı yeniden canlandırmaktır.

Ahlak felsefesinin evrensel olarak algılanıp yaygınlaşmasının insanlara kattığı etkisinin yanı sıra; değişmeden gelen en elzem ahlaki konulara filozofların kendi yaşamlarından yola çıkarak yanıtlar, öneriler ve tavsiyeler vermesi niçin günümüzde Stoalıların tekrar bir ilgi odağı olduğunun bir göstergesidir. Özellikle sosyal medya ortamlarında Stoacı grupları dışardan anlaşılabilecek ölçüde yaşam tarzlarına bu felsefeyi uyguladıklarını görüntülüyorken, çeşitli kamplarda buluşulup bu öğretinin nasıl yaşama adapte edileceği üzerine bir çeşit yaşam koçluğu sunulmaktadır. Toplumsal düzende anlam aramak bir yana bireyin kendine yönelmesini ve kendini sorgulamasını sağlayan bu öneriler, belki de çağımız sorunları karşısında en çok ihtiyaç duyulan rehberdir.

Stoacıların felsefe tarihinde öğretileri, tekrar düşünülüp temellendirildiği için önemli bir yere sahiptirler. Kozmopolit yani dünya vatandaşı olarak, doğa yasalarına tabii insanlar olarak herkesi eşit görürler. Bu anlayışları aydınlanma dönemiyle birlikte tekrar gün yüzüne çıkmış, filozoflarca siyaset felsefesi temelinde irdelenmiştir. Yukarıda değindiğimiz ve çıkarsadığımız metotlar ile felsefe tarihine yeni bir ivme kazandırmış, insanların hayatlarının çekilmez olduğu durumlarda kurtulmalarını sağlayan öğretileriyle Stoalılar pratik felsefeye derin içerik kazandırmışlardır. 


\section{KAYNAKÇA}

\section{Antik Kaynaklar}

M. Aur. Medit. (= Marcus Aurelius Antoninus, Meditianos) Kullanılan Çeviri: Marcus Aurelius Antoninus, Kendime Düşünceler. Çev. C. Eskin. İstanbul 2009.

Cic. Off. (= Marcus Tullius Cicero, De Officiis) Kullanılan Çeviri: Yükümlülükler Üzerine. Çev. C. Çevik. İstanbul 2013.

Cic. Philip. (= Marcus Tullius Cicero, Philippicae) Kullanılan Çeviri: Marcus Tullius Cicero, Philippicae Söylevleri. Çev. G. Özaktürk. Ankara 1998.

Sen. De Tran. (= Lucius Annaeus Seneca, De Tranquilliate Animi) Kullanılan Çeviri: Ruh Dinginliği Üzerine. Çev. B. Demiriş. İstanbul 1999.

Sen. Cons. (= Lucius Annaeus Seneca, Consolationes) Kullanılan Çeviri: Teselliler. Çev. K. Sarıalioğlu. İstanbul 2010.

Sen. De Clem. (= Lucius Annaeus Seneca, De Clementia) Kullanılan Çeviri: Hoşgörü ve Ruh Dinginliği Üzerine. Çev. B. Demiriş. İstanbul 2014.

\section{Modern Literatür}

Achenbach B. Gerd (2010). Zur Einfuhrung der Philosophischen Praxis. Köln 2010.

Açıkgöz M. (2006). Sextus Empirikus ve Şüphe. Ankara 2006.

Akarsu B. (1982). Mutluluk Ahlakı. İstanbul. 1982.

Anthony B., (1987). Marcus Aurelius, A Biography. New Haven and London 1987.

Arslan M. (2001). "Hellenistik Dönem'e Damgasını Vuran Felsefe Sistemleri; Epikurosçuluk ve Stoacılık -II-". Ark. San 101-102 (2001) 37-40.

Becker L. C. (2003). "Human Health and Stoic Moral Norms". Journal of Medicine and Philosophy 28/2 (2003) 221-238.

Filiz Ş. (2018). Felsefi Sağaltım. İstanbul 2018.

Hadot P. (2012). Ruhani Alıştırmalar ve Antik Felsefe. Çev. K. Gürkan. İstanbul 2012.

Kenny A. (2018). Batı Felsefesinin Yeni Tarihi. Çev. S. Uslu. İstanbul 2018.

Öztürk H. \& Demir N. (2018). Felsefi Propedotik. İstanbul 2018.

Peters E. F. (2004). Antik Yunan Felsefesi Sözlüğ̈̈. Çev. H. Hünler. İstanbul 2004.

Stokes P. (2018) Dünyanın En Büyük 100 Düşünürü. Çev. E. Çayırezmez. İstanbul 2018.

Toprak B. Epiktetos (1946). Düşünceler ve Sohbetler. İstanbul 1946.

Toprak B. Epiktetos (1994). Düşünceler ve Sohbetler. İstanbul 1994.

Wahler H. (2013). Philosophische Lebensberatung: Begriff, Theorie und Methoden. Marburg 2013. 